\title{
ANALISIS PEMBUATAN MEDIA PEMBELAJARAN DALAM MATA KULIAH PENDIDIKAN MULTIMEDIA OLEH MAHASISWA PRODI TEKNOLOGI PENDIDIKAN IKIP MATARAM
}

\author{
Wiwien Kurniawati ${ }^{1}$ dan Muhtar Ahmad ${ }^{2}$ \\ Prodi Teknologi Pendidikan, FIP IKIP Mataram \\ E-mail: Wiwienkurniawati@ikipmataram.ac.id
}

\begin{abstract}
Abstrak: Penelitian ini dilakukan berdasarkan pentingnya media pembelajaran dalam proses kegiatan belajar mengajar didalam kelas. Tujuan dalam penelitian ini yaitu untuk mengetahui sejauh mana kemampuan Mahasiswa dalam pembuatan media pembelajaran yang layak digunnakan dalam proses pembelajaran. Dalam penelitian ini, peneliti menggunakan metode penelitian deskriptif kuantitatif, teknik pengumpulan data yang digunakan adalah observasi, dan angket. Teknik analisis data berdasarkan kriteria kelayakan media pembelajaran, yaitu aspek Pewarnaan, aspek Pemakaian Kata dan Bahasa, aspek Tampilan pada Layar, aspek Penyajian, aspek Animasi dan Suara. Berdasarkan hasil uji kelayakan oleh ahli media untuk pembuatan media pembelajaran oleh Mahasiswa pada mata kuliah pendidikan multimedia di program studi Teknologi Pendidikan, perolehan persentase untuk setiap aspek yaitu aspek Pewarnaan $57 \%$, aspek Pemakaian Kata dan Bahasa $55 \%$, aspek Tampilan pada Layar 58 $\%$, aspek Penyajian $57 \%$, aspek Animasi dan Suara $56 \%$ yang artinya media pembelajaran yang dibuat oleh Mahasiswa dalam kategori Layak untuk digunakan dalam proses pembelajaran. Sedangkan untuk uji kelayakan ahli materi memiliki 3 aspek, yaitu aspek Kelayakan Isi, aspek Kelayakan Penyajian, aspek Kontekstual. Hasil analisis kelayakan oleh ahli materi diperoleh persentase untuk masing-masing aspek yaitu, aspek Kelayakan Isi $99 \%$, aspek Kelayakan Penyajian $87 \%$, dan aspek Kontekstual $88 \%$, dimana semua aspek dalam kategori Sangat Layak. Hal ini dapat dilihat dari kesesuaian antara media yang dibuat sesuai dengan pemanfaatan dan tujuan pembelajaran. sehingga hal ini dapat disimpulkan bahwa Mahasiswa memiliki kemampuan yang layak dalam pembuatan media pembelajaran untuk digunakan dalam proses pembelajaran.
\end{abstract}

\section{Kata Kunci: Media Pembelajaran, Pendidikan Multimedia}

\section{PENDAHULUAN}

Dalam perkembangan dunia yang semakin kompleks belakangan ini, Indonesia sebagai salah satu negara bangsa (nation state) mengalami tantangan yang cukup berat dalam berbagai aspek kehidupan, termasuk kehidupan dalam bidang pendidikan. Rendahnya mutu pendidikan yang disebabkan oleh rendahnya kualitas pembelajaran yang terjadi di sekolah tidak pelak lagi telah berimplikasi terhadap kualitas sumber daya manusia yang dihasilkan oleh lembaga pendidikan itu sendiri.Berbicara soal kualitas pendidikan, tidak dapat dilepaskan dari proses pembelajaran di ruang kelas. Pembelajaran di ruang kelas mencakup dua aspek penting yakni guru dan siswa.

Guru mempunyai tugas mengajar dan siswa belajar. Mengajar adalah mengkomunikasikan sesuatu kepada seseorang atau sekelompok orang dengan maksud agar mereka mengetahui atau mengerti apa yang diajarkan oleh guru kepadanya (Depdikbud dalam Suka, (1982:18). Sedangkan belajar dapat diartikan sebagai proses perubahan tingkah laku melalui interaksi antara individu dengan lingkungannya (Hamalik,1990:4).Media sebagai salah satu komponen dalam sistem itu, mempunyai fungsi sebagai sarana komunikasi non-verbal. Sebagai salah satu 
komponen sistem, berarti media mutlak harus ada atau harus dimanfaatkan di dalam setiap pembelajaran. Dikatakan demikian sebab jika salah satu komponen itu tidak ada maka hasil yang diperoleh tidak akan maksimal.

Dengan demikian saat belajar mereka masih memerlukan peragaan langsung. Selanjutnya, pada lapisan skematis anak sudah agak besar dan akan lebih mudah belajar bila anak diberikan/dibantu dengan gambar.

Dalam proses pembelajaran, setiap guru hendaknya memiliki media pembelajaran. Media pembelajaran merupakan komponen pembelajaran yang meliputi bahan dan peralatan. media pembelajaran dapat meningkatkan kualitas pembelajaran siswa di ruang kelas dengan harapan dapat lebih memahami keberadaan media dan perannya dalam sebuah proses pembelajaran. meia pemebelajaran memeliki peran penting dalam setiap proses pembelajaran, salah satunya dapat memberikan pengalaman bermakna bagi peserta didik.

Dalam tataran praksis media dapat dirancang melalui lima langkah antara lain: (1) media harus dirancang sesederhana mungkin sehingga jelas dan mudah dipahami oleh siswa; (2) media hendaknya dirancang sesuai dengan pokok bahasan yang akan diajarkan; (3) media hendaknya dirancang tidak terlalu menjelimet dan tidak membuat anak-anak menjadi bingung; (4) media hendaknya dirancang dengan bahanbahan yang sederhana dan mudah didapat, tetapi tidak mengurangi makna dan fungsi media itu sendiri; (5) media dapat dirancang dalam bentuk model, gambar, bagan berstruktur, dan lain-lain, tetapi dengan bahan yang murah dan mudah didapat sehingga tidak menyulitkan guru dalam merancang media dimaksud.

Yang dimaksud dengan Pembelajaran Multimedia adalah suatu kegiatan belajar mengajar di mana dalam penyampaian bahan pelajaran yang disajikan kepada peserta didik, pendidik menggunakan atau menerapkan berbagai perangkat media pembelajaran. Adapun media pembelajaran itu sangatlah beraneka macam, baik itu dalam bentuk media cetak, media / alat peraga ataupun media elektronik. Penggunaan media elektronik / komputer, berikut dengan pemanfaatan hardware, software dan alat - alat pendukung lainnya dalam proses pembelajaran di dalam kelas. Komputer merupakan suatu alat yang canggih dan lengkap, karena dengan satu unit komputer yang baik dapat difungsikan untuk berbagai keperluan, dan seorang guru yang jeli tentunya dapat memanfaatkan perangkat canggih tersebut untuk keperluan pembelajaran.

Bagi jurusan teknologi pendidikan yang sudah mengadakan ala-talat tersebut, sudah semestinya para pendidik dianjurkan supaya dapat memanfaatkannya dalam kegiatan pembelajaran. Karena disamping mahasiswa memperoleh pengalaman baru dalam pembelajaran. Dan yang tak kalah pentingnya adalah metode pembelajaran seperti ini sangat sejalan dengan perkembangan ilmu pengetahuan dan teknologi.

Media pembelajaran merupakan bagian integral dalam sistem pembelajaran. Penggunaan media pembelajaran harus didasarkan pada memilihan tepat sehingga dapat memperbesar arti dan fungsi dalam menunjang efektivitas dan efisiensi proses pembelajaran (Sumiati dan Asra, 2008:159). Sedangkan menurut Heinich (dalam Azhar Arsyad, 2013: 3) media sebagai perantara 
yang mengantar informasi antara sumber dan penerima. Media pembelajaran diartikan sebagai segala sesuatu yang dapat digunakan untuk menyalurkan pesan (message), meransang pikiran, perasaan, perhatian dan kemauan siswa sehingga dapat mendorong proses belajar.

\section{METODE PENELITIAN}

Penelitian ini merupakan penelitian deskriptif kuantitatif. Penelitian pengambaran tujuan dari proses pembelajaran dan mengukurnya berdasarkan kriteria penilaian tertentu Penelitian ini akan menghasilkan media pembelajaran yang efektif untuk diunakan dalam proses pembelajran dikelas oleh guru.

Kajian prinsip pendidikan yang dievaluasi menekankan pada prinsip dasar dalam dimensi proses. Konteks pembelajaran dianalisis dalam konteks pendidikan formal terfokus pada kajian kurikulum yang diuji relevansinya. Studi kasus dapat berkontribusi pada pemahaman yang bersifat umum, pada kejadian bersifat naturalistik. Kejadian atau hal-hal yang dimaksud dapat memaknai proses evaluasi mata kuliah pendidikan multimedia, dan untuk beberapa kasus dapat disimpulkan sebagai suatu studi naturalistik yang bersifat umum.

Penelitian ini dilaksanakan pada bulan April 2018 di program studi Teknologi Pendidikan IKIP Mataram, dengan Subjek Mahasiswa.

Jenis data dari uji coba yang dilakukan ini berupa data kualitatif dan data kuantitatif sebagai penunjang. Data kuantitatif diperoleh dari instrumen validasi kepada ahli media untuk memvalidasi hasil pembuatan media yang di buat oleh Mahasiswa dalam Mata Kuliah Pendidikan Multimedia, hasil angket yang di isi oleh responden
(Mahasiswa), dan hasil observasi selama proses pembelajaran di dalam kelas.

Teknik Pengumpulan data yang digunakan adalah observasi yang dilakukan untuk memperoleh data yang relevan dengan penelitian. Proses dari kegiatan ini yaitu dengan jalan mengadakan pengamatan secara langsung sehingga dapat diperoleh data yang relevan dengan subyek penelitian. Observasi dilakukan untuk mengetahui bagaimana Mahasiswa membuat media pembelajran yang layak an efektif untuk digunakan dalam emebelajran. Observasi akan dilakukan dalam kelas saat kegiatan belajar mengajar dan di lingkungan kampus.

Selain obeservasi, teknik pengumpulan data lain yang digunakan adalah angket yang digunakan untuk mendapatkan data tentang bagaimana tanggapan Mahasiswa dalam proses pembelajaran di dalam kelas, sehinngga kita bisa mengetahui apakah proses pembelajaran sudah relevan dengan kurikulum atau tidak.

Teknik Analisis Data yaitu Validitas Konstruk dan validasi isi. Pengujian validitas konstruk dapat menggunnakan pendapat para ahli. Setelah instrumen di konstruksi teori tertentu, dan selanjutnya dikosntruksikan kepada ahli minimal 3 orang. Berdasarkan pendapat para ahli, instrumen dapat digunakan tanpa perbaikan, dengan perbaikan, atau harus di rombak seluruhhnya. Seangkan Pengujian validitas isi dan konstruk dapat dibantu dengan kisikisi instrumen. Selanjutnya adalah mengujivaliditas butir-butir instrumen, yang dilakukan dengan melakukan uji coba analisis item .

Teknik Analisis Deskriptif. Penelitian deskriptif hanya menjelaskan, memaparkan, dan menggambarkan secara objektif data yang diperoleh. Langkah analisis deskriptif yaitu dengan mencari Skor dan Presentase 
dari data yang ada. Langkah-langkah yang ditempuh adalam analisis data adalah sebagai berikut:

1. Membuat tabel distribusi jawaban angket

2. Menentukan skor jawaban responden, yaitu dengan menghitung jumlah masing-masing butir pertanyaan: Sangat Kurang $=1$, Kurang $=2$, Baik $=3$, Sangat Baik $=4$.

3. Menghitung setiap skor yang diperoleh responden

4. Mencari persentase kelayakan media yang di hasilkan oleh Mahasiswa dan kelayakan ahli materi.

\section{HASIL PENELITIAN}

Hasil analisis penelitian ini didapat dari angket tertutup dengan skala likert sebagai instrumennya yang telah disusun terdiri dari 30 pertanyaan tentang kegiatan yang dilakukan selama proses pembelajaran. Angket tersebut kemudian dibagikan kepada Mahasiswa. Data yang diperoleh kemudian akan melalui perhitungan skor berdasarkan angket yang telah diisi oleh Mahasiswa.

\section{Uji Validitas Ahli Media dan Ahli Materi}

Uji validitas ahli media dilihat dari 5 aspek, yaitu pewarnaan, pemakaian kata dan bahasa, tampilan pada layar, penyajian, dan animasi dan suara.

Penilaian ahli media disajikan dalam tabel dibawah ini:

\begin{tabular}{|l|c|}
\hline \multicolumn{1}{|c|}{ Aspek } & Persentase \\
\hline Pewarnaan & $57 \%$ \\
\hline $\begin{array}{l}\text { Pemakaian Kata } \\
\text { dan Bahasa }\end{array}$ & $55 \%$ \\
\hline $\begin{array}{l}\text { Tampilan pada } \\
\text { Layar }\end{array}$ & $58 \%$ \\
\hline Penyajian dan & $57 \%$ \\
\hline Animasi & \\
\hline
\end{tabular}

Suara

\section{Uji Validitas Ahli Materi}

Untuk Uji validitas ahli materi dilihat dari 3 aspek, yaitu aspek kelayakan isi, aspek kelayakan penyajian, dan aspek kontekstual.

Untuk penilaian ahli materi terdapat dalam tabel dibawah ini:

\begin{tabular}{|l|c|}
\hline \multicolumn{1}{|c|}{ Aspek } & Persentase \\
\hline Kelayakan Isi & $99 \%$ \\
\hline $\begin{array}{l}\text { Kelayakan } \\
\text { Penyajian }\end{array}$ & $87 \%$ \\
\hline Kontekstual & $88 \%$ \\
\hline
\end{tabular}

\section{PEMBAHASAN}

Penelitian ini dimaksudkan untuk mengetahui kemampuan Mahasiswa dalam pembuatan media pembelajaran pada mata kuliah Pendidikan Multimedia.

Pada penelitian ini angket tertutup dengan skala likert sebagai instrumennya yang telah disusun terdiri dari 30 pertanyaan tentang kegiatan yang dilakukan selama proses pembelajaran. Angket tersebut kemudian dibagikan kepada Mahasiswa. Data yang diperoleh kemudian akan melalui perhitungan skor berdasarkan angket yang telah diisi oleh Mahasiswa.

Pada tabel uji validasi ahli media terdapat 5 aspek yang harus diuji kelayakannya, yaitu aspek Pewarnaan, aspek Pemakaian Kata dan Bahasa, aspek Tampilan pada Layar, aspek Penyajian, aspek Animasi dan Suara. Berdasarkan hasil uji kelayakan oleh ahli media untuk pembuatan media pembelajaran oleh Mahasiswa pada mata kuliah pendidikan multimedia di program studi Teknologi Pendidikan, perolehan persentase untuk setiap aspek yaitu aspek Pewarnaan $57 \%$, aspek Pemakaian Kata dan Bahasa $55 \%$, aspek Tampilan pada Layar $58 \%$, aspek 
Penyajian $57 \%$, aspek Animasi dan Suara $56 \%$ yang artinya media pembelajaran yang dibuat oleh Mahasiswa dalam kategori Layak untuk digunakan dalam proses pembelajaran.

Sedangkan untuk uji kelayakan ahli materi memiliki 3 aspek, yaitu aspek Kelayakan Isi, aspek Kelayakan Penyajian, aspek Kontekstual. Hasil analisis kelayakan oleh ahli materi diperoleh persentase untuk masing-masing aspek yaitu, aspek Kelayakan Isi $99 \%$, aspek Kelayakan Penyajian $87 \%$, dan aspek Kontekstual 88 $\%$, dimana semua aspek dalam kategori Sangat Layak

\section{SIMPULAN}

Penelitian ini merupakan penelitian deskriptif kuantitatif. Penelitian yang menggambaran tujuan dari sebuah pembelajaran dan mengukurnya berdasarkan kriteria penilaian tertentu Penelitian menghasilkan media pembelajaran yang layak dan efektif untuk digunakan dalam proses pembelajaran dikelas oeh guru .

Kelayakan media yang dibuat oleh mahasiswa juga sudah layak dan efektif untuk digunakan dalam pembelajaran, hal ini dibuktikan dengan uji analisis dari ahli media dan ahli materi dan kesesuaian antara media yang dibuat sesuai dengan pemanfaatan dan tujuan pembelajaran.

Hal ini dibuktikan dari perolehan persentase untuk uji kelayakan ahli media pada setiap aspek yaitu aspek Pewarnaan 57 $\%$, aspek Pemakaian Kata dan Bahasa $55 \%$, aspek Tampilan pada Layar $58 \%$, aspek Penyajian $57 \%$, aspek Animasi dan Suara $56 \%$ yang artinya media pembelajaran yang dibuat oleh Mahasiswa dalam kategori Layak untuk digunakan dalam proses pembelajaran.

Sedangkan untuk uji kelayakan ahli materi memiliki 3 aspek, yaitu aspek Kelayakan Isi, aspek Kelayakan Penyajian, aspek Kontekstual. Hasil analisis kelayakan oleh ahli materi diperoleh persentase untuk masing-masing aspek yaitu, aspek Kelayakan Isi $99 \%$, aspek Kelayakan Penyajian $87 \%$, dan aspek Kontekstual 88 $\%$, dimana semua aspek dalam kategori Sangat Layak

\section{DAFTAR PUSTAKA}

Azhar, A. (2013). Media Pembelajaran. Jakarta: PT. Raja Grafindo Persada.

Hasan, H. S. (2008). Evaluasi Kurikulum. Bandung: Remaja Rosda Karya

Sugiono. (2010). Statistik untuk Penelitian. Bandung: Alfabeta

Suharsimi, A \& Jabar. (2010). Evaluasi Program Pendidikan. Jakarta: Bhineka Aksara

Sumiati \& Asra. (2008). Metode Pembelajaran. Bandung: CV Wacana Prima.

Usman. (2007). Metodologi Penelitian Sosial. Jakarta: Bumi Aksras.

Miarso, Y. (2009). Menyemai Benih Teknologi Pendidikan. Jakarta: Kencana Prenada Media Group.

Abidin, Z. (2003). Media dan Media Pembelajaran. jakarta: PT. Raja Grafindo Persada 